\title{
Sex-related differences of urethane and sodium valproate effects on Ki-67 expression in urethane-induced lung tumors of mice
}

\author{
DONATAS STAKIŠAITIS ${ }^{1,2}$, RAMINTA MOZŪRAITÉ ${ }^{2}$, DOVILĖ KAVALIAUSKAITÉ ${ }^{2}$, LINA ŠLEKIENË ${ }^{2}$, \\ INGRIDA BALNYTÉ ${ }^{2}$, NOMEDA JUODŽIUKYNIENE $\dot{B}^{3}$ and ANGELIJA VALANČIŪTE் ${ }^{2}$ \\ ${ }^{1}$ Laboratory of Cancer Epidemiology, National Cancer Institute, LT-08660 Vilnius; \\ ${ }^{2}$ Department of Histology and Embryology, Lithuanian University of Health Sciences, LT-44307 Kaunas; \\ ${ }^{3}$ Veterinary Academy, Lithuanian University of Health Sciences, LT-47181 Kaunas, Lithuania
}

Received October 20, 2016; Accepted February 1, 2017

DOI: $10.3892 / e t m .2017 .4324$

\begin{abstract}
The aim of the present study was to evaluate sex differences in tumorigenesis by assessing the number of $\mathrm{Ki}-67$-positive cells [Ki-67(+)] in urethane-induced mice lung tumors and the effect of sodium valproate (NaVP) in BALB/c mice. Gonad-intact and gonadectomized female and male mice were divided into the following groups: i) Treated with urethane, ii) treated with urethane and NaVP and iii) gonad-intact or gonadectomized control. Urethane (total $50 \mathrm{mg} /$ mouse) was injected intraperitoneally. The NaVP $0.4 \%$ solution was administered orally for 6 months. Histologically, lung tumors were divided into adenomas and adenocarcinomas and assessed immunohistochemically using antibodies against Ki-67. The Ki-67(+) was calculated per one $\mathrm{mm}^{2}$ of a tumor. In adenomas, $\mathrm{Ki}-67(+)$ in the urethane-treated gonad-intact males was significantly higher than in females $(\mathrm{P}=0.001)$ and in castrated males $(\mathrm{P}<0.01)$; Ki-67(+) in adenomas of the urethane-treated gonad-intact males was significantly higher than in urethane-NaVP-treated ones $(\mathrm{P}<0.04)$. No significant differences were found in analogous female groups. In adenocarcinomas, $\mathrm{Ki}-67(+)$ in urethane-treated gonad-intact males was significantly higher than in females and gonadectomized mice of both sexes $(\mathrm{P}<0.001)$, and in ovariectomized females was significantly higher than in ovary-intact group $(\mathrm{P}=0.01)$. A significantly higher number of Ki-67(+) cells were observed in gonad-intact adenocarcinomas of the urethane-NaVP-treated
\end{abstract}

Correspondence to: Professor Angelija Valančiūte, Department of Histology and Embryology, Lithuanian University of Health Sciences, Mickevičiaus g. 9, LT-44307 Kaunas, Lithuania

E-mail: angelija.valanciute@1smuni.lt

Abbreviations: $\mathrm{Ki}-67(+)$, the number of $\mathrm{Ki}-67$ positive cells; NaVP, sodium valproate, NSCLC, non-small cell lung cancer; ROS, reactive oxygen species; ER, estrogen receptor; GABA, gamma-aminobutyric acid; GABRQ, GABA-A receptor $\theta$ subunit

Key words: urethane, mouse, lung tumor, sodium valproate, sex differences, Ki-67 females compared with the urethane-treated ones $(\mathrm{P}<0.001)$. Comparing between urethane-NaVP-treated gonadectomized males and females in adenocarcinomas, determined that Ki-67(+) was significantly lower in females $(\mathrm{P}=0.005)$. In adenocarcinomas, Ki-67(+) in urethane-NaVP-treated gonadectomized males and females was significantly lower than in gonad-intact mice of the same sex $(\mathrm{P}<0.001)$. In summary, gonadectomy with NaVP treatment decreased Ki-67(+) in adenocarcinomas for mice of both sexes. The results of the present study indicate sex-related differences in mice lung tumorigenesis, and a sex-related effect of $\mathrm{NaVP}$ on progression in urethane-induced BALB/c mice lung tumors.

\section{Introduction}

Lung cancer is the leading cause of cancer-associated mortality in many parts of the world (1) and the epidemiology of human lung cancer differs between men and women (2). There are two main types of lung cancer: Small cell lung cancer and non-small cell lung cancer (NSCLC). Approximately $80 \%$ of all lung cancers are classified histologically as NSCLCs, of which adenocarcinoma is the most common type $(3,4)$. The proportion of histological types denotes sex-related differences, with adenocarcinoma being more common among women, and differing survival rates between men and women $(5,6)$. A large prospective study of men and women from the general population of Denmark revealed that increased blood testosterone level was associated with an increased risk (30-80\%) of early death following cancer diagnosis (7). A 2008 study in humans revealed that androgens may serve a greater role in lung carcinogenesis than previously thought (8). Androgen-regulated target genes are involved in several biological processes of the lungs in both sexes of mice (9). Estrogen, progesterone, androgen receptors are present in malignant lung tissue, indicating that gonadal hormones serve a role in lung cancer biology (8-14).

Urethane-induced lung tumor mice models have been accepted for use in investigations of human lung adenocarcinoma, and in mouse models of lung tumors urethane has been used as a carcinogen that specifically induces the development of lung adenoma and adenocarcinoma from alveolar type II pneumocytes and Clara cells $(15,16)$. Chemo-preventive 
studies have been performed using the urethane-induced lung cancer mouse model to study lung adenomas or adenocarcinomas $(4,17)$.

The histone deacetylase inhibitor sodium valproate $(\mathrm{NaVP})$ has potent antitumor effects in a variety of in vitro and in vivo systems, and has demonstrated encouraging results in early clinical trials in monotherapy and in combination with demethylating and/or cytotoxic agents $(18,19)$. It was also demonstrated that NaVP could interact with estrogen and androgen receptors in cell culture (20). A recent study by the present authors reported sex-related NaVP effect particularities of the urethane-induced mouse lung tumorigenesis initiation in BALB/c mice (21). NaVP in the urethane-induced $\mathrm{BALB} / \mathrm{c}$ mouse model was found to synergistically enhance urethane lung tumorigenicity in testes-intact male mice. When comparing the number of tumors per mouse in non-castrated urethane-treated and urethane-NaVP-treated males, tumors were found significantly more often in males treated with urethane in combination with NaVP compared with females, where no such NaVP effect was observed (21). Comparing the number of tumors per mouse in urethane-NaVP-treated ovary-intact and urethane-NaVP-treated ovariectomized females, lung tumors were found significantly more often in urethane-NaVP-treated ovariectomized females and NaVP was associated with a significant decrease in the number of adenocarcinomas in ovariectomized BALB/c female mice (22).

The Ki-67 protein is a well-established prognostic marker for various types of cancer including NSCLC (23-25). Ki-67 is expressed in proliferating cells throughout the cell cycle, but not in quiescent $\left(\mathrm{G}_{0}\right)$ cells (26). Ki-67 serves an important role in acquiring biological malignant potential in early-stage of lung adenocarcinoma (27) and it has been demonstrated that high levels of Ki-67 in tumor cells are a poor prognostic factor for 3-year overall survival among these patients (28).

The aim of the present study was to evaluate sex differences in urethane-induced mice lung tumorigenesis by investigating the effect of NaVP on the expression of Ki-67-positive cells [Ki-67(+)] in urethane-induced lung adenomas and adenocarcinomas of gonad-intact and castrated male and female $\mathrm{BALB} / \mathrm{c}$ mice groups, and in non-treated and NaVP-treated mice of both sexes. The results of the present study indicate the sex-related differences in the progression of tumorigenesis and the effect of NaVP on these processes in urethane-induced $\mathrm{BALB} / \mathrm{c}$ mice.

\section{Materials and methods}

Animal model. The BALB/c mouse lung tumor model is one of the assays used to investigate cancer modulative agents. A total of $180 \mathrm{BALB} / \mathrm{c}$ mice were purchased from the Animal Facility of the Lithuanian University of Health Sciences Veterinary Academy (Kaunas, Lithuania). All experiments were performed in compliance with the relevant laws and institutional guidelines. The permission of the State Food and Veterinary Service of Lithuania (Vilnius, Lithuania) to use experimental animals for the current study was obtained (No. 2; 25/07/2013). Mice were housed in standard colony cages and acclimated for 1 week prior to the study; they were housed at $21 \pm 1^{\circ} \mathrm{C}$ with constant humidity and a $12 \mathrm{~h}$ light/dark cycle. A commercial pellet diet was provided ad libitum. In total, $180 \mathrm{BALB} / \mathrm{c}$ mice were used in the experiment, divided into 12 groups ( $\mathrm{n}=15$ in each group). Intact mice were divided into male and female groups, each of which was randomly divided into the following 3 groups: i) Treated with urethane; ii) treated with urethane and NaVP; and iii) intact control. Ovariectomized female mice and castrated male mice were divided into the same groups. Mice gonadectomy was performed prior to begining of the experiment at the age of 5-6 weeks: Male gonadectomy was performed by orchiectomy using the scrotal approach, and female ovariectomy was performed by midline laparotomy. The following preparations for anesthesia were used for gonadectomy: Sedator $1 \mathrm{mg} / \mathrm{kg}$ intramuscular injection (i.m.) (Eurovet Animal Health B.V., Bladel, Netherlands), Bioketan $75 \mathrm{mg} / \mathrm{kg}$ i.m. (Vetoquinol Biowet, Gorzów, Poland), and Atipam $2 \mathrm{mg} / \mathrm{kg}$ i.m. as an antidote of Sedator (Eurovet Animal Health B.V.). In the urethane-treated groups, $10 \mathrm{mg}$ urethane/mouse (Sigma-Aldrich; Merck KGaA, Darmstadt, Germany) in $0.2 \mathrm{ml} 0.9 \%$ sodium chloride solution (AB Sanitas, Kaunas, Lithuania) was administered twice per week via intraperitoneal injection (5 doses; total dose $50 \mathrm{mg} /$ mouse). Four of the urethane-treated groups were also treated with NaVP (Sigma-Aldrich; Merck KGaA). The total duration of the experiment and NaVP treatment was 6 months. The NaVP $0.4 \%$ aqueous solution was the only source of drinking water offered to NaVP-treated animals ad libitum in aluminum foil-wrapped bottles to avoid light decomposition. Controls and non-NaVP urethane-treated groups were provided with fresh drinking water ad libitum. Male and female mice were studied simultaneously under the same conditions; the urethane-NaVP-treated castrated male and ovariectomized female mice were first provided with $\mathrm{NaVP}$ one week following castration, together with the first injection of urethane, at 6-7 weeks of age.

Mice were euthanized in $\mathrm{CO}_{2}$ cages $(19.05 \times 12.71 \times 29.21 \mathrm{~cm})$. The $\mathrm{CO}_{2}$ flow rate was $1.5 \mathrm{l} / \mathrm{min}$ and the final concentration of $\mathrm{CO}_{2}$ was $20 \%$. Rapid unconsciousness was achieved with minimal distress to the animals. Lungs were carefully removed and fixed in a 10\% neutral buffered formalin solution at room temperature for 2 weeks and taken for macroscopic evaluation as previously described $(21,22)$. The percentage of animals with lung tumors and the mean number of tumors per tumor-bearing mouse were recorded only in mice that survived up to the end of the experiment in each group. Some animals died naturally during the first five months of the experiment. The numbers of mice that survived in each group are shown in Table I.

Histological and immunohistochemical investigation of lungs. Following macroscopic examination, lungs were divided into lobules. Lobules were embedded in paraffin and cut into $3 \mu \mathrm{m}$ sections using a LEICA RM 2155 microtome (Leica Microsystems, Inc., Buffalo Grove, IL, USA). Standard hematoxylin and eosin (HE) staining was performed. A light microscope was used to visualise the slides. Immunohistochemical staining using Ki-67 antibodies was performed as follows. Histological samples were added to Superfrost adhesion histological slides (Thermo Fisher Scientific, Inc., Waltham MA, USA), straightened in a water bath, dried on a heating board and placed in a thermostat at $37^{\circ} \mathrm{C}$ for $24 \mathrm{~h}$. Slides had been stored at $56^{\circ} \mathrm{C}$ for $2 \mathrm{~h}$ prior 
to staining. A standard deparaffinisation technique was conducted. Briefly, slides were placed into xylene for $5 \mathrm{~min}$ three times at room temperature and then into ethanol of different concentrations ( $90 \%$ ethanol for $2 \mathrm{~min}, 80 \%$ ethanol for $2 \mathrm{~min}, 70 \%$ ethanol for $2 \mathrm{~min}$ ). The slides were placed in distilled water for $1 \mathrm{~min}$ three times. Epitope retrieval was performed using an epitope retrieval solution ( $\mathrm{pH}$ 9; Dako; Agilent Technologies, Inc., Santa Clara, CA, USA) in a pressure cooker $\left(110^{\circ} \mathrm{C}\right.$ for $3 \mathrm{~min}$ at $\left.15 \mathrm{psi}\right)$. Slides were stained using the Thermo Shandon cover plate system (Thermo Fisher Scientific, Inc.). Peroxidase blocking was performed with a peroxidase blocking solution (Dako REAL ${ }^{\mathrm{TM}}$; Dako; Agilent Technologies, Inc.) with a Tween 20 wash buffer for $10 \mathrm{~min}$ at room temperature (Dako; Agilent Technologies, Inc.). Primary antibody solution (anti-Ki-67 [SP6]; 1:50; ab16667, Abcam, Cambridge, UK) was added with incubation for $1 \mathrm{~h}$ at room temperature. Slides were washed with Tween 20 wash buffer, and the secondary antibody was added (EnVision ${ }^{\mathrm{TM}}$ FLEX+ MOUSE (LINKER), K8002 K8021; Dako; Agilent Technologies, Inc.) which was followed by the FLEX/HRP (EnVision $^{\text {TM }}$ FLEX/HRP SM802 REF K8000 K8002 K8023; Dako; Agilent Technologies, Inc.), both with incubation for $30 \mathrm{~min}$ at room temperature. Slides were again washed with Tween 20, a 3,3'diaminobenzidine chromogen (Dako; Agilent Technologies, Inc.) was added, and slides were washed once more. Slides were counterstained using Mayer's hematoxylin and covered with covering glasses. Histological slides were evaluated using an OLYMPUS BX 40F4 microscope (Olympus Corporation, Tokyo, Japan) supplied with the XC30 digital camera (Olympus Corporation). A magnification of $\mathrm{x} 4$ was used to evaluate the tumor size and position in the lobule and a magnification of $\mathrm{x} 40$ was used to evaluate the tumor type and malignancy. Histomorphometric analysis was performed by two independent researchers using the Cellsens Dimension 2010 software (version 1.3; Olympus Corporation).

Mice lung tumors were divided into two groups according to their morphology (Fig 1): Adenoma (Fig. 1A and C) and adenocarcinoma (Fig. 1B and D). The criteria used to divide urethane-induced mice lung tumors into adenoma and adenocarcinoma were as previously described (29-31).

Proliferating cell count. A total of 5 tumors were randomly selected from each group. The number of proliferating cells was counted by calculating the number of $\mathrm{Ki}-67$ positive cells [Ki-67(+)] in each field for adenoma and adenocarcinoma using the Olympus XC30 microscopic camera (magnification, x40; Olympus Corporation) and the Cellsens Dimension 2010 software. When calculating the Ki-67(+), all fields of vision were tested. Tumors were of unequal size and they contained different numbers of visual fields. The calculation was performed for all fields, which caused there to be an unequal number of fields calculated in each group. The area of each field was $23817 \mu \mathrm{m}^{2}$, and the number of Ki-67(+) was recalculated per $1 \mathrm{~mm}^{2}$.

Statistical analysis. Statistical analysis was performed using SPSS version 20.0 (IBM SPSS, Armonk, NY, USA). Data on $\mathrm{Ki}-67(+)$ were expressed as the median and range and evaluated as nonparametric data. The Kruskal-Wallis test was used to evaluate differences among the groups. The Mann-Whitney
Table I. Tumor induction in the investigated mice groups.

\begin{tabular}{llcc}
\hline Groups & Sex & Number & $\begin{array}{c}\text { Mice with } \\
\text { tumors }(\%)\end{array}$ \\
\hline $\begin{array}{l}\text { Gonad-intact } \\
\text { Control }\end{array}$ & Male & 15 & 0 \\
& Female & 15 & 0 \\
Urethane-treated & Male & 13 & 100 \\
Urethane-NaVP-treated & Female & 10 & 100 \\
& Male & 11 & 100 \\
Gonadectomized & Female & 13 & 100 \\
Control & & & \\
Urethane-treated & Male & 15 & 13.3 \\
& Female & 12 & 0 \\
Urethane-NaVP-treated & Male & 15 & 100 \\
& Female & 12 & 100 \\
& Male & 9 & 100 \\
& Female & 14 & 100 \\
\hline
\end{tabular}

NaVP, sodium valproate.

$U$-test was used to compare $\mathrm{Ki}-67(+)$ expression and to calculate the differences between the adenoma and adenocarcinoma scores among the groups. $\mathrm{P}<0.05$ was considered to indicate a statistically significant difference.

\section{Results}

Survival of mice in investigated groups. Of the 180 mice in the current study, 154 mice survived until the end of the study. All mice of both sexes in the intact control and intact NaVP-treated groups survived until the end of the experiment 6 months later. In the male urethane-treated group, from 15 mice, 13 survived; in the urethane-NaVP male group, 11 mice survived; in the female urethane-treated group, 10 mice survived; in the urethane-NaVP-treated group, 13 mice survived. Autopsies of the mice that succumbed during the fifth month revealed that in intact urethane- and urethane-NaVP-treated groups, benign lung tumors had developed in all cases and data from these animals were not included in the statistical assessments.

All castrated control males survived until the end of the experiment. A total of 12 control ovariectomized female mice survived, 12 female mice in the urethane-treated group survived, and 9 castrated male mice in the urethane-NaVP-treated group survived until the end of the experiment. Data from surviving mice is presented in Table I.

Lung tumor initiation in gonad-intact, gonadectomized urethane- and urethane-NaVP-treated mice groups. Lung tumors were not observed in intact control male and female mice or in the control gonadectomized female mice, following both macroscopic and microscopic evaluation. Small $(<1 \mathrm{~mm})$, sporadic tumors were found in the lungs of 2 mice from the castrated male control group ( 2 tumors in one mouse and 1 in the lung of the other mouse). All gonad-intact and 


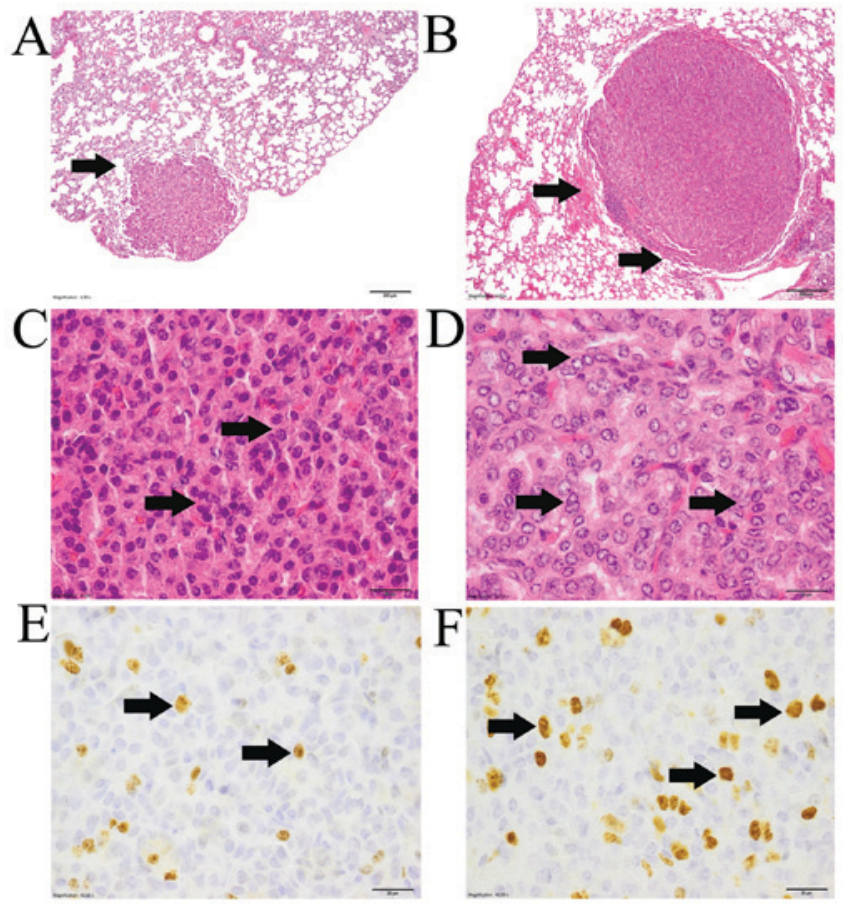

Figure 1. Adenoma and adenocarcinoma type tumors. HE staining and immunohistochemistry with Ki-67 antibody. (A) Adenoma. Arrow indicates that there is no compression to neighboring tissues. HE staining, magnification $\mathrm{x} 4$. Scale $200 \mu \mathrm{m}$. (B) Adenocarcinoma. Arrows indicate compression to surrounding tissues. HE staining, magnification $\mathrm{x} 4$. Scale $200 \mu \mathrm{m}$. (C) Adenoma. Arrows indicate cell nuclei that are of the same size and shape. Cells also are of similar size and shape. Cytoplasm is eosinophilic. HE staining, magnification $\times 40$. Scale $20 \mu \mathrm{m}$. (D) Adenocarcinoma Arrows indicate cell nuclei that are of different size and shape. Cells also are of different shape and size. HE staining, magnification x40. Scale $20 \mu \mathrm{m}$. (E) Adenoma of gonad-intact urethane-NaVP-treated male mice. Arrows indicate mitotic (proliferating) cells. Immunohistochemistry with Ki-67 antibody, magnification $x 40$. Scale $20 \mu \mathrm{m}$. (F) Adenocarcinoma of gonad-intact urethane-NaVP-treated male mice. Arrows indicate mitotic (proliferating) cells. Immunohistochemistry with Ki-67 antibody, magnification $x 40$. Scale $20 \mu \mathrm{m}$. HE, hematoxylin and eosin; NaVP, sodium valproate.

gonadectomized urethane-treated mice of both sexes developed lung tumors (Table I).

Lung adenoma and adenocarcinoma in mice groups by histological examination data. HE-stained slides of mouse lung lobules were examined histopathologically and tumors in each group were divided into adenomas and adenocarcinomas (Fig. 1). Adenomas were characterized as having clear borders, cells and nuclei of a similar size, and no compression of neighboring tissues (Fig. 1A and C). Adenocarcinomas compressed the neighboring tissues and nuclear pleomorphism was observed; cells also differed in size and shape (Fig. 1B and D). As shown in Fig. 1E, Ki67 (an indicator of cell proliferation) was observed in the adenoma of gonad-intact urethane-NaVP-treated male mice. As shown in Fig. 1F, Ki-67 antibody was also observed in the adenocarcinoma of gonad-intact urethane-NaVP-treated male mice. In adenocarcinoma-type tumors, mitotic figures were observed, some nuclei looked 'empty', and their size differed (Fig. 2A), the nuclei were atypical, the position and number of nucleoli were different in various cells (Fig. 2B), hemorrhage was observed (Fig. 2C) and part of the adenocarcinoma was surrounded by cuboidal epithelial cells (Fig. 2D).

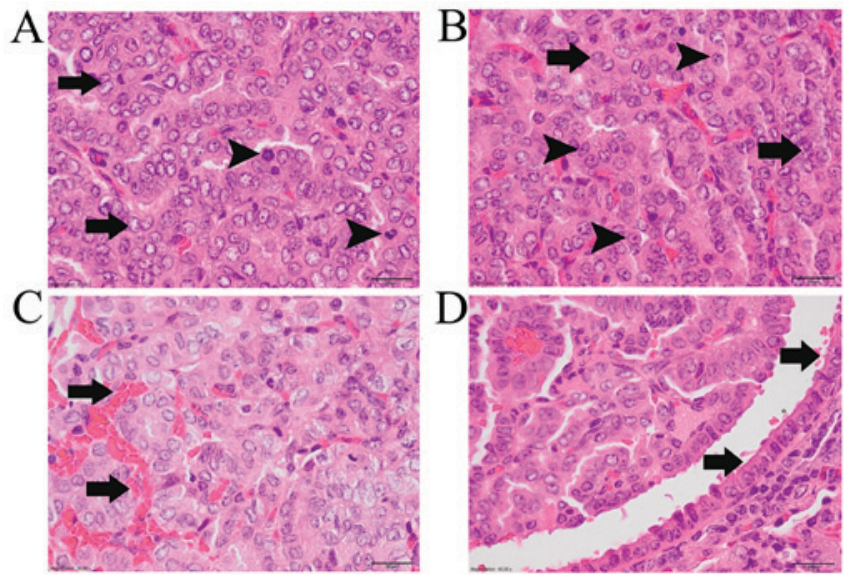

Figure 2. Adenocarcinomas. hematoxylin and eosin staining, magnification x40. Scale $20 \mu \mathrm{m}$. (A) Arrows indicate 'empty' cell nuclei, black arrowheads indicate mitotic figures in the cells. (B) Arrows indicate atypical nuclei of different size and shape. Arrowheads indicate nuclei with different number of nucleoli. Nucleoli are of different size, shape and position in the nucleus. (C) Arrows indicate hemorrhage in the tumor. (D) Arrows indicate cuboidal epithelium that covers the tumor.

Ki-67(+) in adenomas of mice groups. The number of fields investigated for adenoma and adenocarcinoma tumors in mice groups is presented in Table II. Ki-67(+) in the gonad-intact male urethane-treated group adenomas was significantly higher than in the adenomas of urethane-treated gonad-intact females $(\mathrm{P}<0.001)$. In the urethane-treated groups, $\mathrm{Ki}-67(+)$ was found to be significantly higher in adenomas of gonad-intact males compared with castrated males $(\mathrm{P}<0.01)$, whereas no significance difference was found between analogous female groups. In the gonad intact males, Ki-67(+) was significantly higher in the urethane-treated group compared with the urethane-NaVP-treated group $(\mathrm{P}<0.04)$, and no significant difference was found between analogous female mice groups. There was no significant difference in Ki-67(+) between adenomas in urethane-NaVP-treated non-castrated males and gonad-intact urethane-NaVP-treated female groups (Table II).

Ki-67(+) in adenocarcinomas of mice groups. There was a significant sex-related difference in Ki-67(+) between the adenocarcinomas of urethane-treated gonad-intact males and females; Ki-67(+) was significantly higher in male compared with female mice ( $\mathrm{P}<0.001$; Fig. 3A). No significant sex-related difference in number of proliferating cells in adenocarcinomas was found between urethane-NaVP-treated gonad-intact males and females (Fig. 3B).

$\mathrm{Ki}-67(+)$ was significantly higher in adenocarcinomas of urethane-treated gonad-intact males than in urethane-treated castrated males $(\mathrm{P}<0.001$; Fig. 3A). By contrast, $\mathrm{Ki}-67(+)$ in the urethane-treated ovariectomized female mice was found to be significantly higher than in the gonad-intact urethane-treated females ( $\mathrm{P}=0.01$; Fig. 3A).

A significantly higher Ki-67(+) was observed in the gonad-intact urethane-NaVP-treated female group than in gonad-intact urethane-treated females $(\mathrm{P}<0.001$; Table II). No significant difference in Ki-67(+) was found between urethane-treated and urethane-NaVP-treated testes-intact males (Table II). 
Table II. The numbers of Ki-67 cell in lung adenomas and adenocarcinomas of investigated mice groups.

\begin{tabular}{|c|c|c|c|c|c|}
\hline \multirow[b]{2}{*}{ Groups } & \multirow[b]{2}{*}{ Sex } & \multicolumn{2}{|r|}{ Adenoma } & \multicolumn{2}{|c|}{ Adenocarcinoma } \\
\hline & & $\begin{array}{l}\text { Tested } \\
\text { fields, } \mathrm{n}\end{array}$ & $\begin{array}{l}\mathrm{Ki}-67(+) \text { per } \mathrm{mm}^{2}, \\
\text { median (range) }\end{array}$ & $\begin{array}{l}\text { Tested } \\
\text { fields, } \mathrm{n}\end{array}$ & $\begin{array}{c}\mathrm{Ki}-67(+) \text { per } \\
\mathrm{mm}^{2}, \text { median (range) }\end{array}$ \\
\hline \multicolumn{6}{|l|}{ Gonad intact } \\
\hline \multirow[t]{2}{*}{ Control } & Male & 0 & 0 & 0 & 0 \\
\hline & Female & 0 & 0 & 0 & 0 \\
\hline \multirow[t]{2}{*}{ Urethane-treated } & Male & 26 & $314.90^{\mathrm{a}, \mathrm{b}, \mathrm{c}}(0.00-755.76)$ & 56 & $335.89^{\mathrm{h}}(41.99-713.78)$ \\
\hline & Female & 26 & $104.97(0.00-545.83)$ & 48 & $125.96^{\mathrm{i}}(0.00-671.79)$ \\
\hline \multirow[t]{2}{*}{ Urethane-NaVP-treated } & Male & 14 & $125.96^{\mathrm{d}}(0.00-461.86)$ & 35 & $377.88(0.00-755.76)$ \\
\hline & Female & 21 & $83.97^{\mathrm{e}}(0.00-335.89)$ & 83 & $293.91(0.00-797.75)$ \\
\hline \multicolumn{6}{|l|}{ Gonadectomized } \\
\hline \multirow[t]{2}{*}{ Control } & Male & 0 & 0 & 0 & 0 \\
\hline & Female & 0 & 0 & 0 & 0 \\
\hline \multirow[t]{2}{*}{ Urethane-treated } & Male & 23 & $125.96(0.00-545.83)$ & 30 & $146.95(0.00-671.79)$ \\
\hline & Female & 20 & $104.97^{f}(0.00-419.87)$ & 34 & $230.93^{\mathrm{j}}(41.99-545.83)$ \\
\hline \multirow[t]{2}{*}{ Urethane-NaVP-treated } & Male & 12 & $83.97^{\mathrm{g}}(0.00-293.91)$ & 26 & $230.93^{\mathrm{k}}(41.99-419.87)$ \\
\hline & Female & 24 & $125.96(0.00-377.88)$ & 74 & $125.96(0.00-335.90)$ \\
\hline
\end{tabular}

${ }^{\mathrm{a}} \mathrm{P}<0.04$ vs. adenoma of gonad-intact urethane-NaVP-treated males, ${ }^{\mathrm{b}} \mathrm{P}<0.001 \mathrm{vs}$. adenoma of gonad-intact urethane-treated females, ${ }^{\mathrm{c}} \mathrm{P}<0.01 \mathrm{vs}$. adenoma of gonadectomized urethane-treated males, ${ }^{\mathrm{d}} \mathrm{P}<0.003 \mathrm{vs}$. adenocarcinoma of urethane-NaVP-treated gonad-intact males, ${ }^{\mathrm{e}} \mathrm{P}<0.001 \mathrm{vs}$. adenocarcinoma of urethane-NaVP-treated gonad-intact females, ${ }^{\mathrm{P}} \mathrm{P}=0.01 \mathrm{vs}$. adenocarcinoma in the urethane-treated ovariectomized females, ${ }^{\mathrm{g}} \mathrm{P}<0.02$ vs. adenocarcinoma of urethane-NaVP-treated gonadectomized males, ${ }^{\mathrm{h}} \mathrm{P}<0.001 \mathrm{vs}$. adenocarcinoma of gonad-intact urethane-treated females, ${ }^{\mathrm{P}}<0.001$ vs. adenocarcinoma of gonad-intact urethane-NaVP-treated females, ${ }^{\mathrm{j}} \mathrm{P}<0.001$ vs. adenocarcinoma of gonadectomized urethane-NaVP-treated females, ${ }^{\mathrm{k}} \mathrm{P}<0.005$ vs. adenocarcinoma of gonadectomized urethane-NaVP-treated females. NaVP, sodium valproate; Ki-67(+), Ki-67 positive cell.

A similar $\mathrm{Ki}-67(+)$ in adenocarcinomas was found for the urethane-treated gonadectomized males and females (Fig. 3A). However, a significant sex-related difference was found between urethane-NaVP-treated gonadectomized males and females; Ki67(+) was significantly lower in female adenocarcinomas ( $\mathrm{P}=0.005$; Fig. 3B; Table II).

For both male and female mice, Ki-67(+) was significantly lower in the gonadectomized urethane-NaVP-treated groups compared with the gonad-intact groups (both $\mathrm{P}<0.001$; Fig. 3B). No significant difference was observed when comparing Ki-67(+) between urethane- and urethane-NaVP-treated males in the adenocarcinomas from castrated male mice; however, Ki-67(+) was significantly decreased in the urethane-NaVP-treated ovariectomized female adenocarcinomas compared with the urethane-treated female group $(\mathrm{P}<0.001$; Table II).

A comparison of $\mathrm{Ki}-67(+)$ in adenomas and adenocarcinomas of the same group revealed significantly higher Ki-67(+) in adenocarcinomas compared with adenomas in the urethane-treated ovariectomized females $(\mathrm{P}=0.01)$, urethane-NaVP-treated gonad-intact males $(\mathrm{P}<0.003)$, and females $(\mathrm{P}<0.001$; Table II), as well as gonadectomized males $(\mathrm{P}<0.02)$. Increased $\mathrm{Ki}-67(+)$ in adenocarcinomas vs. adenomas was noted in all groups apart from urethane-NaVP-treated gonadectomized females.

\section{Discussion}

Sex differences of lung cancer pathogenesis in mouse models have previously been reported $(32,33)$. Carcinogen-induced sex-related lung cancer and spontaneous pulmonary adenomas in mice are determined by multiple genetic loci (34). Compared with human lung adenocarcinoma, the mouse-urethane model exhibits similar histological features and molecular changes, and serves as a valuable tool for understanding basic lung tumor biology and developing novel tumor intervention strategies $(17,35)$. BALB/c mice are considered susceptible to the tumorogenetic effects of urethane (36), which initiates the development of lung tumors in the airway epithelial cells of mice (35). In this system, tumor development follows a well-characterized pattern: Hyperplasia, adenoma and adenocarcinoma manifest at $\sim 8,16,40$ weeks following urethane treatment, respectively, and some of the adenomas develop into adenocarcinomas over time $(21,29,35,37)$. To date, there have been few studies investigating the effect of medicinal products on this transformation and of sex-related differences on tumorigenesis initiation or progression.

Ki-67 expression serves as an indicator of increased proliferation of lung cancer cells in experimental and clinical models $(38,39)$. Previous immunohistochemical studies demonstrated that carcinogen-induced $\mathrm{Ki}-67$ expression in the lung tissue is associated with the progression of lung tumors $(40,41)$. Ki-67 is expressed in the nuclei of proliferating cells during all active cell cycle phases $\left(\mathrm{G}_{1}, \mathrm{~S}, \mathrm{G}_{2}\right.$, and mitosis) but not in quiescent cells $\left(\mathrm{G}_{0}\right)$. This makes it a reliable marker for tumor progression assessment (41) and it has been used to evaluate cancer treatment strategies (42). The effects of medicinal products on progression or suppression of 
A

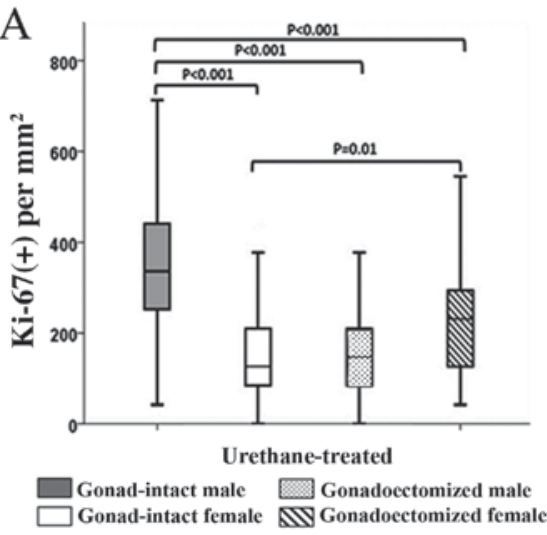

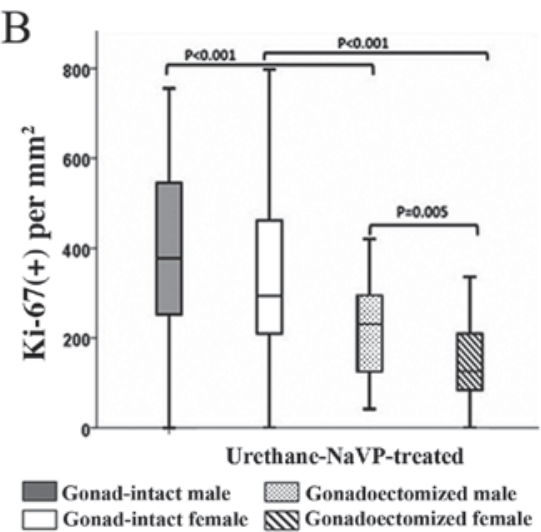

Figure 3. Ki-67(+) cells in $1 \mathrm{~mm}^{2}$ of tumor in the urethane- and urethane-NaVP-treated, gonad-intact and gonadectomized male and female mice groups in adenocarcinoma. (A) Urethane-treated mice groups. (B) Urethane-NaVP-treated mice groups. Ki-67(+), the number of Ki-67 positive cells; NaVP, sodium valproate.

tumor cell proliferation, or the mechanisms responsible for the transformation of adenomas to adenocarcinomas, remain to be elucidated. To the best of our knowledge, there are currently no data concerning sex-related differences in Ki-67 expression at various stages of lung tumors in $\mathrm{BALB} / \mathrm{c}$ mice.

NaVP is recognized as a histone deacetylase (HDAC) inhibitor, which induces the differentiation of transformed cells and exhibits antitumor properties in clinical and preclinical studies via modulation of multiple pathways including cell cycle arrest, cell differentiation and apoptosis (19,43-45). The sex-related differences in HDAC regulation of cells have previously been reported (46). In mice models, HDAC serves a dual role in tumorigenesis; it is oncosuppressive in the early stages and oncogenic in established tumor cells (47).

The results of the present study found that all urethane-treated BALB/c mice groups developed tumors with no sex-related differences in the number of tumors detected per mouse. To the best of our knowledge, there are no published data on sex-related differences in urethane-induced tumorigenesis initiation in $\mathrm{BALB} / \mathrm{c}$ mice. It has been reported that urethane-induced lasting lung inflammation and DNA injury in BALB/c mice is associated with glycolytic stress, with an increase in lactate and reactive oxygen species (ROS) in the lungs (48). The primary candidates that cause DNA damage and urethane-promoted epithelial-mesenchymal transition are glycolytic levels and related ROS; these processes are not only secondary side effects of cancer transformation, they also directly initiate tumorigenesis (48). In the present study, $\mathrm{NaVP}+$ urethane increased the number of tumors per mouse in testes-intact BALB/c male; however, no such synergistic effect was observed in gonad-intact female mice. These data indicate that testosterone, together with urethane, may serve an important role in the initiation of tumorigenesis in male testes-intact BALB/c mice. The NaVP action mechanism may also be associated with the effect of gonadal hormones; NaVP treatment was associated with an increase in testosterone levels and a reduction in estrogen serum levels in the absence of significant effects on gonadotropins (49).

There is experimental evidence demonstrating the effect of NaVP on ROS and the potential role of oxidative stress in NaVP-associated toxicity (50). Compared with females, males express lower levels of antioxidants and consequently experience a higher rate of oxidative damage by ROS (51-53). Genetic overexpression of antioxidant enzymes in females may be associated with the activation of estrogen receptors (54) and testosterone appears to diminish the efficacy of the defense system against oxidative stress (55). NaVP causes a significant increase in the number of tumors in ovariectomized urethane-NaVP-treated BALB/c female mice compared with ovariectomized urethane-treated BALB/c female mice (22). It has been demonstrated that serum estradiol concentration in female mice significantly decreases following ovariectomy, whereas testosterone concentration is slightly increased, as secretion from the adrenal cortex may be augmented in ovariectomized female mice $(56,57)$. This imbalance in gonad hormones, with an increased testosterone level in urethane-NaVP-treated ovariectomized female mice, may be responsible for the increased initiation of lung tumors in such mice. The increased initiation of mice lung tumors may also be associated with the absence of the estrogen receptor- $\beta$ (ER $\beta$ ) tumor expression in gonadectomized mice, as the decreased expression of $E R \beta$ in mouse lungs is recognized as a lung tumor-related factor (58). The ERß is the predominant form of estrogen receptor expressed in mouse lungs (59). Ovariectomy in mice increases their vulnerability to oxidative damage; however, decreased estrogen level does not fully explain the differences in antioxidant defenses (55).

The present study found that Ki-67(+) in gonad-intact male urethane-treated adenomas was significantly higher than in the adenomas of urethane-treated gonad-intact females; however no such sex difference was observed in $\mathrm{Ki}-67(+)$ in adenomas from gonadectomized mice. NaVP treatment decreased $\mathrm{Ki}-67(+)$ in gonad-intact male adenomas only, and Ki-67(+) was significantly higher in adenomas of urethane-treated gonad-intact males compared with castrated males. These data indicate that testosterone is involved together with urethane in the tumorigenesis of testes-intact $\mathrm{BALB} / \mathrm{c}$ mice via activation of adenoma cell proliferation. $\mathrm{Ki}-67$ is a proliferating cell nuclear antigen that is closely correlated with DNA synthesis and is thus an important indicator of the tumor cell proliferation (60). In various types of cancer, including lung cancer (61), the level of Ki-67 expression represents the 
proliferation index and $\mathrm{Ki}-67$ overexpression is a predictor of tumor progression (42).

The mechanisms by which Ki-67 regulates cancer progression are unclear. The results of the present study suggest a significant sex-related difference in $\mathrm{Ki}-67(+)$ of adenocarcinomas in urethane-treated gonad-intact males and females: The number of $\mathrm{Ki}-67(+)$ was higher in adenocarcinomas in males compared with adenocarcinomas in females. Testosterone has previously been reported to stimulate the growth of lung cancer cells that express androgen receptors (12). Furthermore, Mikkonen et al (11) suggested that androgen nuclear receptors serve a role in lung cancer biology, and that castration significantly decreases Ki-67(+). According to data of the present study, ovariectomy, conversely, had the opposite effect-Ki-67 expression increased in adenocarcinomas of gonadectomized urethane-treated females as compared with gonad-intact urethane-treated females. These data support the suggestion that testosterone may be important not only for the initiation of urethane-induced tumorigenesis, but also for its progression in males. This may also be the case in urethane-treated ovariectomized BALB/c female mice; although estradiol serum levels significantly decrease following ovariectomy, testosterone concentration is augmented in ovariectomized female mice due to increased secretion from the adrenal cortex $(51,52)$. Ovariectomy decreases ER $\beta$ expression in the cells and this may inhibit the progression of tumorigenesis (53). A previous study determined that urethane-induced mice lung tumors in the estrogen treatment group increased the expression of ER $\beta$ and that estrogen receptor antagonists prevented the progression of urethane-induced mice lung tumors (62). Moreover, preclinical data suggest that estrogen is a driver of lung cancer (13). Estrogen promotes the development of lung adenocarcinoma and this may be associated with the activation of signaling pathways in which ERs serve an important role in the progression of lung tumors in mice $(63,64)$. In the present study, lung tumor progression in mice was found to be sensitive to estrogen, indicating that tumor grade was higher in ovary-intact than in ovariectomized mice (63). The G-protein-coupled ER mediates the $17 \beta$-estradiol-induced progression of NSCLCs (65). It has been reported that $17 \beta$-estradiol and IL- 6 may act synergistically to enhance the sex bias in experimental inflammation and tumor progression (66); overexpression of IL-6 may induce chronic inflammation, leading to the progression of urethane-induced lung cancer in BALB/c mice (67). Estrogen and progesterone receptors are present in malignant lung tissue, and the gonadal hormones that bind these receptors serve a role in lung inflammation and lung cancer $(10,30)$. ER $\alpha$ inhibits lung cancer proliferation, whereas ER $\beta$ increases cell proliferation (30). Anti-estrogens that inhibit ERs and aramatose inhibitors that block estrogen production from androgens may prevent the formation of lung tumors $(14,29)$. The cytoplasmic estrogen-ER complex transduces nongenomic signals interacting with the epidermal factor signaling pathway, leading to DNA synthesis and cell proliferation (13).

The results of the present study suggest that NaVP treatment has no effect on $\mathrm{Ki}-67(+)$ in urethane-induced adenocarcinomas in males, whereas it increases Ki-67(+) in gonad-intact female mice. Gonadectomy accompanied by NaVP treatment induced a significant decrease in $\mathrm{Ki}-67(+)$ in adenocarcinomas of both sexes, whereas a decrease was observed in females only when comparing adenocarcinomas of the urethane-treated and urethane-NaVP-treated gonadectomized mice groups. These data are in agreement with previous reports demonstrating that NaVP causes a significant decrease in adenocarcinoma numbers in ovariectomized urethane-NaVP-treated females; the deprivation of estrogens and treatment with NaVP may delay the transformation of adenomas into adenocarcinomas in ovariectomized urethane-NaVP-treated BALB/c mice (22). NaVP treatment induces a gonadal hormone imbalance in both male and female non-epileptic rats; in female rats, this effect is supported by reduced estradiol and progesterone levels combined with unaltered testosterone levels $(49,68,69)$. Furthermore, NaVP also interacts with estrogen and androgen receptors differently when steroid hormones are present (20). Exposure to NaVP resulted in the downregulation of enzyme-encoding genes in early steroidogenesis (70). NaVP enhances the estradiol-induced activation of both estrogen receptor types, with a greater effect in $\operatorname{ER} \beta$, and treatment with $\beta$-estradiol stimulates the growth of lung tumor cells (71). This is consistent with the findings of the present study, which suggest that NaVP increases Ki-67(+) in gonad-intact urethane-treated female mice adenocarcinomas in the presence of estrogen. Due to the complexity of hormone homeostasis, there are many potential targets for active chemicals. Therefore, NaVP may affect more than one component of tumor progression in the tumorigenetic Ki-67 system, in conjunction with gonadal hormones.

The sex-related effect of NaVP on Ki-67 expression in mouse lung tumors may also be associated with gamma-aminobutyric acid (GABA) modulative functions, as NaVP potentiates GABAergic functions (72). The GABA-A receptor subunits form a functional chloride channel, and the GABA-A receptor is rapidly activated by $\mathrm{NaVP}(73,74)$. NaVP has been shown to enhance the sex-related urinary excretion of chloride in rats (75) and to reduce the activity of GABA-degrading enzymes (76). The effect of NaVP on basal GABA levels in cells may be sex-specific (77). A previous study reported that endogenous GABA release in ovariectomized rats was only $60-70 \%$ of that in intact animals (78). In male rats, castration has been reported to decrease the activity of GABAergic neurons, and testosterone replacement therapy prevented the castration-induced decrease in GABA (79). GABA has been found to inhibit tumor growth in mouse models of NSCLC (80). Furthermore, it blocks the proliferation of human airway epithelial HPL1D cell enhancement induced by the cooperative estrogen-tobacco carcinogen-related cyclic adenosine monophosphate (cAMP) signaling downstream (81). GABA interaction with chloride channels may affect the immune response, as lymphocytes have a GABAergic system (82). The GABA-A receptor $\theta$ subunit (GABRQ) forms a functional ionotropic chloride channel (74). GABA-A receptors are found also in cancer cells $(83,84)$ and GABRQ is overexpressed in hepatocellular carcinoma cells. It has been reported that GABA promotes the proliferation of liver cancer cells via the GABRQ (84), therefore high expression of the GABA receptor gene in NSCLC tissues suggests that GABA receptor pathways may serve an important role in the proliferation of these cells. An evaluation of the GABA-A and GABA-B receptors in NSCLC tissues revealed that the expression of GABA receptor 
phenotypes was correlated with sex-related differences in carcinogenesis and its progression $(83,85)$. Administering a combination of estrogen and progesterone resulted in a greater reduction in GABA-A receptor binding in mouse forebrain membranes, indicating that gonadal steroids contribute to the modulation of GABA-A receptor binding in both male and female mice (85).

Additional factors contributing to the NaVP sex-related induction of cell proliferation in mice lung tumorigenesis may include the association between GABA-related mechanisms and $\mathrm{K}-\mathrm{Cl}$ cotransport activity. Intracellular chloride regulation and the control of GABA-A receptor signaling occur via the $\mathrm{K}-\mathrm{Cl}$ cotransporter (86). The K- $\mathrm{Cl}$ cotransporter exports potassium and chloride ions, leading to a decrease in intracellular chloride (87), and the activity of the $\mathrm{K}-\mathrm{Cl}$ cotransporter was reported as a possible mechanism in the modulation of tumor development and progression (88). To the best of our knowledge, there are no data on $\mathrm{K}-\mathrm{Cl}$ expression in urethane-induced mice lung tumor cells; however, it has been reported that expression of the $\mathrm{K}-\mathrm{Cl}$ cotransporter is lower in male rat neurons compared with female ones (89). It is widely recognized that chloride serves an important role in tumorigenesis, as the intracellular chloride concentration is a critical messenger in cell proliferation processes $(90,91)$.

In the current study, a higher Ki-67(+) was observed in adenocarcinomas compared with adenomas for all groups apart from urethane-NaVP-treated gonadectomized females. $\mathrm{NaVP}$ treatment increased the expression of proliferating cells in lung adenocarcinomas from gonad-intact mice of both sexes. These findings support the suggestion that the synergism of gonadal hormones and NaVP is an important factor in the progression of mice lung adenocarcinomas.

In conclusion, the results of the present study have identified sex differences in the urethane-induced BALB/c mice lung cancer progression pathophysiology. NaVP treatment decreases the number of $\mathrm{Ki}-67$ positive cells in adenomas from gonad-intact males; however, no such effect was observed in gonad-intact females. In females, the effect of NaVP treatment is dependent on the presence of gonadal hormones; $\mathrm{NaVP}$ stimulates lung adenocarcinoma cell proliferation in gonad-intact urethane-treated female mice, and suppresses cell proliferation in ovariectomized urethane-treated female mice. The deprivation of sex hormones by gonadectomy combined with NaVP treatment induced a decrease in the number of Ki-67 positive cells in lung tumors from both sexes of mice, which suggests that it is important in adenocarcinogenesis suppression. The sex-related pharmacological mechanisms of $\mathrm{NaVP}$ effects require further investigation in order to elucidate the underlying mechanisms responsible for this.

\section{Acknowledgements}

The present study was supported by the Lithuanian University of Health Science (grant no. V-1238) and a grant (no. MIP-12224/2012) from the Research Council of Lithuania.

\section{References}

1. Siegel R, Ma J, Zou Z and Jemal A: Cancer statistics, 2014. CA Cancer J Clin 64: 9-29, 2014.
2. Harlos C, Musto G, Lambert P, Ahmed R and Pitz MW: Androgen pathway manipulation and survival in patients with lung cancer. Horm Cancer 6: 120-127, 2015.

3. Herbst RS, Heymach JV and Lippman SM: Lung cancer. N Engl J Med 359: 1367-1380, 2008.

4. Wang Y, Rouggly L, You M and Lubet R: Animal models of lung cancer characterization and use for chemoprevention research. Prog Mol Biol Transl Sci 105: 211-226, 2012.

5. Rivera MP: Lung cancer in women: The differences in epidemiology, biology and treatment outcomes. Expert Rev Respir Med 3: 627-634, 2009

6. Fu JB, Kau TY, Severson RK and Kalemkerian GP: Lung cancer in women: Analysis of the national surveillance, epidemiology, and end results database. Chest 127: 768-777, 2005.

7. Orsted DD, Nordestgaard BG and Bojesen SE: Plasma testosterone in the general population, cancer prognosis and cancer risk: A prospective cohort study. Ann Oncol 25: 712-718, 2014.

8. Molina JR, Yang P, Cassivi SD, Schild SE and Adjei AA: Non-small cell lung cancer: Epidemiology, risk factors, treatment, and survivorship. Mayo Clin Proc 83: 584-594, 2008.

9. Bouhaddioui W, Provost PR and Tremblay Y: Expression profile of androgen-modulated microRNAs in the fetal murine lung. Biol Sex Differ 7: 20, 2016.

10. Siegfried JM: Smoking out reproductive hormone actions in lung cancer. Mol Cancer Res 12: 24-31, 2014.

11. Mikkonen L, Pihlajamaa P, Sahu B, Zhang FP and Jänne OA: Androgen receptor and androgen-dependent gene expression in lung. Mol Cell Endocrinol 317: 14-24, 2010.

12. Maasberg M, Rotsch M, Jaques G, Enderle-Schmidt U, Weehle R and Havemann K: Androgen receptors, androgen-dependent proliferation, and 5 alpha-reductase activity of small-cell lung cancer cell lines. Int J Cancer 43: 685-691, 1989.

13. Burns TF and Stabile LP: Targeting the estrogen pathway for the treatment and prevention of lung cancer. Lung Cancer Manag 3: 43-52, 2014.

14. Stabile LP, Rothstein ME, Cunningham DE, Land SR, Dacic S, Keohavong P and Siegfried JM: Prevention of tobacco carcinogen-induced lung cancer in female mice using antiestrogens. Carcinogenesis 33: 2181-2189, 2012.

15. Mason RJ, Kalina M, Nielsen LD, Malkinson AM and Shannon JM: Surfactant protein Cexpression in urethane-induced murine pulmonary tumors. Am J Pathol 156: 175-182, 2000.

16. Cekanova M, Lee SH, Donnell RL, Sukhthankar M, Eling TE, Fischer SM and Baek SJ: Nonsteroidal anti-inflammatory drug-activated gene-1 expression inhibits urethane-induced pulmonary tumorigenesis in transgenic mice. Cancer Prev Res (Phila) 2: 450-458, 2009.

17. Meuwissen R and Berns A: Mouse models for human lung cancer. Genes Dev 19: 643-664, 2005.

18. Wang B, Yang R, Wu Y, Li H, Hu Z, Chen Y and Zou S: Sodium valproate inhibits the growth of human cholangiocarcinoma in vitro and in vivo. Gastroenterol Res Pract 2013: 374593, 2013.

19. Duenas-Gonzalez A, Candelaria M, Perez-Plascencia C, Perez-Cardenas E, de la Cruz-Hernandez E and Herrera LA: Valproic acid as epigenetic cancer drug: Preclinical, clinical and transcriptional effects on solid tumors. Cancer Treat Rev 34: 206-222, 2008.

20. Stempin S, Andres S, Bumke Scheer M, Rode A, Nau H, Seidel A and Lampen A: Valproic acid and its derivatives enhanced estrogenic activity but not androgenic activity in a structure dependent manner. Reprod Toxicol 42: 49-57, 2013.

21. Stakisaitis D, Uleckiene S, Didziapetriene J, Valanciute A, Mozuraite R and Matusevicius P: Sodium valproate enhances urethane tumorigenicity in lungs of male but not female mice. EXCLI J 13: 667-687, 2014.

22. Stakisaitis D, Mozuraite R, Juodziukyniene N, Didziapetriene J, Uleckiene S, Matusevicius P and Valanciute A: Sodium valproate enhances the urethane-induced lung adenomas and suppresses malignization of adenomas in ovariectomized female mice. Int J Endocrinol 2015: 218219, 2015.

23. Tabata K, Tanaka T, Hayashi T, Hori T, Nunomura S, Yonezawa S and Fukuoka J: Ki-67 is a strong prognostic marker of non-small cell lung cancer when tissue heterogeneity is considered. BMC Clin Pathol 14: 23, 2014.

24. Ahn HK, Jung M, Ha SY, Lee JI, Park I, Kim YS, Hong J, Sym SJ, Park J, Shin DB, et al: Clinical significance of Ki-67 and p53 expression in curatively resected non-small cell lung cancer. Tumour Biol 35: 5735-5740, 2014.

25. Juriková M, Danihel L, Polák S S and Varga I: Ki67, PCNA, and MCM proteins: Markers of proliferation in the diagnosis of breast cancer. Acta Histochem 118: 544-552, 2016. 
26. Patruno R, Zizzo N, Zito AF, Catalano V, Valerio P, Pellecchia V, D'Errico E, Mazzone F, Ribatti D and Ranieri G: Microvascular density and endothelial area correlate with $\mathrm{Ki}-67$ proliferative rate in the canine non-Hodgkin's lymphoma spontaneous model. Leuk Lymphoma 47: 1138-1143, 2006.

27. Maki Y, Soh J, Ichimura K, Shien K, Furukawa M, Muraoka T, Tanaka N, Ueno T, Yamamoto H, Asano H, et al: Impact of GLUT1 and Ki-67 expression on early-stage lung adenocarcinoma diagnosed according to a new international multidisciplinary classification. Oncol Rep 29: 133-140, 2013.

28. Kim CH, Lee HS, Park JH, Choi JH, Jang SH, Park YB, Lee MG Hyun IG, Kim KI, Kim HS, et al: Prognostic role of p53 and Ki-67 immunohistochemical expression in patients with surgically resected lung adenocarcinoma: A retrospective study. J Thorac Dis 7: 822-833, 2015.

29. Regala RP, Justilien V, Walsh MP, Weems C, Khoor A Murray NR and Fields AP: Matrix metalloproteinase-10 promotes Kras-mediated bronchio-alveolar stem cell expansion and lung cancer formation. PLoS One 6: e26439, 2011.

30. Kelly-Spratt KS, Philipp-Staheli J, Gurley KE, Hoon-Kim K, Knoblaugh S and Kemp CJ: Inhibition of PI-3K restores nuclear p27Kip1 expression in a mouse model of Kras-driven lung cancer. Oncogene 28: 3652-3662, 2009.

31. Mohr U (ed): International Classification of Rodent Tumors. The Mouse. Springer-Verlag GmbH, Berlin, 2001.

32. Berndt A, Cario CL, Silva KA, Kennedy VE, Harrison DE, Paigen B and Sundberg JP: Identification of fat 4 and tsc22d1 as novel candidate genes for spontaneous pulmonary adenomas. Cancer Res 71: 5779-5791, 2011.

33. Morozkova TS and Kaledin VI: Sex-related differences in the sensitivity to carcinogenic effect of urethane on the lungs in mice are reversed after neonatal androgenization. Bull Exp Biol Med 159: 782-785, 2015.

34. Festing MF, Yang A and Malkinson AM: At least four genes and sex are associated with susceptibility to urethane-induced pulmonary adenomas in mice. Genet Res 64: 99-106, 1994.

35. Malkinson AM: Primary lung tumors in mice as an aid for understanding, preventing and treating human adenocarcinoma of the lung. Lung Cancer 32: 265-279, 2001.

36. Malkinson AM and Beer DS: Major effect on susceptibility to urethan-induced pulmonary adenoma by a single gene in BALB/cBy mice. J Natl Cancer Inst 70: 931-936, 1983.

37. Vultur A, Tomai E, Peebles K, Malkinson AM, Grammatikakis N, Forkert PG and Raptis L: Gap junctional intercellular communication in cells isolated from urethane-induced tumors in $\mathrm{A} / \mathrm{J}$ mice. DNA Cell Biol 22: 33-40, 2003.

38. Yerushalmi R, Woods R, Ravdin PM, Hayes MM and Gelmon KA: Ki67 in breast cancer: Prognostic and predictive potential. Lancet Oncol 11: 174-183, 2010.

39. Martin B, Paesmans M, Mascaux C, Berghmans T, Lothaire P, Meert AP, Lafitte JJ and Sculier JP: Ki-67 expression and patients survival in lung cancer: Systematic review of the literature with meta-analysis. Br J Cancer 91: 2018-2025, 2004.

40. van Diest PJ, van der Wall E and Baak JP: Prognostic value of proliferation in invasive breast cancer: A review. J Clin Pathol 57: 675-681, 2004.

41. Gerdes J, Lemke H, Baisch H, Wacker HH, Schwab U and Stein H: Cell cycle analysis of a cell proliferation-associated human nuclear antigen defined by the monoclonal antibody Ki-67. J Immunol 133: 1710-1715, 1984

42. Dowsett M, Nielsen TO, A'Hern R, Bartlett J, Coombes RC, Cuzick J, Ellis M, Henry NL, Hugh JC, Lively T, et al: Assessment of Ki67 in breast cancer: Recommendations from the International Ki67 in breast cancer working group. J Natl Cancer Inst 103: 1656-1664, 2011

43. Göttlicher M, Minucci S, Zhu P, Krämer OH, Schimpf A, Giavara S, Sleeman JP, Lo Coco F, Nervi C, Pelicci PG and Heinzel T: Valproic acid defines a novel class of HDAC inhibitors inducing differentiation of transformed cells. EMBO J 20 : 6969-6978, 2001.

44. Kawagoe R, Kawagoe H and Sano K: Valproic acid induces apoptosis in human leukemia cells by stimulating both caspase-dependent and -independent apoptotic signaling pathways. Leuk Res 26: 495-502, 2002.

45. Blaheta RA and Cinatl J Jr: Anti-tumor mechanisms of valproate: A novel role for an old drug. Med Res Rev 22: 492-511, 2002.

46. Wang Y, Ye F, Ke Q, Wu Q, Yang R and Bu H: Gender-dependent histone deacetylases injury may contribute to differences in liver recovery rates of male and female mice. Transplant Proc 45: 463-473, 2013
47. Santoro F, Botrugno OA,DalZuffo R,Pallavicini I, Matthews GM, Cluse L, Barozzi I, Senese S, Fornasari L, Moretti S, et al: A dual role for Hdac1: Oncosuppressor in tumorigenesis, oncogene in tumor maintenance. Blood 121: 3459-3468, 2013.

48. Ma X, Deng J, Cao N, Guo Z, Zheng Y, Geng S, Meng M, Lin H, Duan Y and Du G: Lasting glycolytic stress governs susceptibility to urethane-induced lung carcinogenesis in vivo and in vitro. Toxicol Lett 240: 130-139, 2016.

49. von Krogh K, Harjen H, Almas C, Zimmer KE, Dahl E, Olsaker I, Tauboll E, Ropstad E and Verhaegen S: The effect of valproate and levetiracetam on steroidogenesis in forskolin-stimulated H295R cells. Epilepsia 51: 2280-2288, 2010.

50. Chang TK and Abbott FS: Oxidative stress as a mechanism of valproic acid-associated hepatotoxicity. Drug Metab Rev 38: 627-639, 2006

51. Borrás C, Sastre J, Garcia-Sala D, Lloret A, Pallardó FV and Viña J: Mitochondria from females exhibit higher antioxidant gene expression and lower oxidative damage than males. Free Radic Biol Med 34: 546-552, 2003.

52. Malorni W, Campesi I, Straface E, Vella S and Franconi F: Redox features of the cell: A gender perspective. Antioxid Redox Signal 9: 1779-1801, 2007.

53. Ide T, Tsutsui H, Ohashi N, Hayashidani S, Suematsu N, Tsuchihashi M, Tamai $\mathrm{H}$ and Takeshita A: Greater oxidative stress in healthy young men compared with premenopausal women. Arterioscler Thromb Vasc Biol 22: 438-442, 2002.

54. Vina J, Borrás C, Gambini J, Sastre J and Pallardó FV: Why females live longer than males: Control of longevity by sex hormones. Sci Aging Knowledge Environ 2005: pe17, 2005.

55. Bokov AF, Ko D and Richardson A: The effect of gonadectomy and estradiol on sensitivity to oxidative stress. Endocr Res 34: 43-58, 2009.

56. Ninomiya F, Yokohira M, Kishi S, Nakano Y, Yamakawa K, Inoue $\mathrm{T}$, Kuno $\mathrm{T}$ and Imaida $\mathrm{K}$ : Gender-dependent effects of gonadectomy on lung carcinogenesis by 4 -(methylnitrosamino)1-(3-pyridyl)-1-butanone (NNK) in female and male A/J mice. Oncol Rep 30: 2632-2638, 2013.

57. Matsuura S and Suzuki K: Morphological changes in the submandibular glands and in the $\mathrm{X}$ zone of the adrenal gland following ovariectomy in mice. Cell Tissue Res 246: 549-556, 1986.

58. Kawai H, Ishii A, Washiya K, Konno T, Kon H, Yamaya C, Ono I, Minamiya $\mathrm{Y}$ and Ogawa J: Estrogen receptor alpha and beta are prognostic factors in non-small cell lung cancer. Clin Cancer Res 11: 5084-5089, 2005

59. Patrone C, Cassel TN, Pettersson K, Piao YS, Cheng G, Ciana P, Maggi A, Warner M, Gustafsson JA and Nord M: Regulation of postnatal lung development and homeostasis by estrogen receptor beta. Mol Cell Biol 23: 8542-8552, 2003.

60. Zhang B, Deng SM, Guo LC, Dong JJ, Zhu YB, Gao Y, Wang ZX and Cho WC: Effect of gemcitabine on the uptake of (18)F-fluorodeoxyglucose and (18)F-fluorothymidine in lung adenocarcinoma A549 cells and the animal tumor model. J Cancer Res Ther 12: 271-276, 2016.

61. Jakobsen JN and Sørensen JB: Clinical impact of ki-67 labeling index in non-small cell lung cancer. Lung Cancer 79: 1-7, 2013.

62. Tang H, Liao Y, Zhang C, Chen G, Xu L, Liu Z, Fu S, Yu L and Zhou S: Fulvestrant-mediated inhibition of estrogen receptor signaling slows lung cancer progression. Oncol Res 22: 13-20, 2014.

63. Hammoud Z, Tan B, Badve S and Bigsby RM: Estrogen promotes tumor progression in a genetically defined mouse model of lung adenocarcinoma. Endocr Relat Cancer 15: 475-483, 2008

64. Tang H, Liao Y, Xu L, Zhang C, Liu Z, Deng Y, Jiang Z, Fu S, Chen $\mathrm{Z}$ and Zhou S: Estrogen and insulin-like growth factor 1 synergistically promote the development of lung adenocarcinoma in mice. Int J Cancer 133: 2473-2482, 2013.

65. Liu C, Liao Y, Fan S, Tang H, Jiang Z, Zhou B, Xiong J, Zhou S, Zou M and Wang J: G protein-coupled estrogen receptor (GPER) mediates NSCLC progression induced by $17 \beta$-estradiol (E2) and selective agonist G1. Med Oncol 32: 104, 2015.

66. Cho J, Kim L, Li Z, Rose NR, Talor MV and Njoku DB: Sex bias in experimental immune-mediated, drug-induced liver injury in BALB/c mice: Suggested roles for Tregs, estrogen, and IL-6. PLoS One 8: e61186, 2013.

67. Narayan $C$ and Kumar A: Constitutive over expression of IL-1 $\beta$, IL-6, NF- $\kappa \mathrm{B}$, and Stat3 is a potential cause of lung tumorgenesis in urethane (ethyl carbamate) induced Balb/c mice.J Carcinog 11: 9,2012 . 
68. Gregoraszczuk E, Wójtowicz AK, Taubøll E and Ropstad E: Valproate-induced alterations in testosterone, estradiol and progesterone secretion from porcine follicular cells isolated from small- and medium-sized ovarian follicles. Seizure 9: 480-485, 2000.

69. Roste LS, Taubøll E, Isojarvi JI, Berner A, Berg KA, Pakarinen AJ, Huhtaniemi IT, Knip M and Gjerstad L: Gonadal morphology and sex hormones in male and female Wistar rats after long-term lamotrigine treatment. Seizure 12: 621-627, 2003.

70. Gustavsen MW, von Krogh K, Taubøll E, Zimmer KE, Dahl E, Olsaker I, Ropstad E and Verhaegen S: Differential effects of antiepileptic drugs on steroidogenesis in a human in vitro cell model. Acta Neurol Scand Suppl 14-21, 2009.

71. Stabile LP, Davis AL, Gubish CT, Hopkins TM, Luketich JD, Christie N, Finkelstein S and Siegfried JM: Human non-small cell lung tumors and cells derived from normal lung express both estrogen receptor alpha and beta and show biological responses to estrogen. Cancer Res 62: 2141-2150, 2002.

72. Löscher W: Basic pharmacology of valproate: A review after 35 years of clinical use for the treatment of epilepsy. CNS Drugs 16: 669-694, 2002.

73. Armijo JA, de las Cuevas I and Adín J: Ion channels and epilepsy. Rev Neurol 30 (Suppl 1): S25-S41, 2000 (In Spanish).

74. Fritschy JM and Mohler H: GABAA-receptor heterogeneity in the adult rat brain: Differential regional and cellular distribution of seven major subunits. J Comp Neurol 359: 154-194, 1995.

75. Grikiniene J, Stakisaitis D and Tschaika M: Influence of sodium valproate on sodium and chloride urinary excretion in rats, gender differences. Pharmacology 75: 111-115, 2005.

76. Dodge JC, Illig AM, Snyder PJ and Badura LL: GABA levels within the medial preoptic area: Effects of chronic administration of sodium valproic acid. Psychoneuroendocrinol 25 : 519-534, 2000

77. Godin Y, Heiner L, Mark J and Mandel P: Effects of DI-n-propylacetate, and anticonvulsive compound, on GABA metabolism. J Neurochem 16: 869-873, 1969.

78. Ondo J, Mansky T and Wuttke W: In vivo GABA release from the medial preoptic area of diestrous and ovariectomized rats. Exp Brain Res 46: 69-72, 1982

79. Grattan DR and Selmanoff $M$ : Regional variation in gamma-aminobutyric acid turnover: Effect of castration on gamma-aminobutyric acid turnover in microdissected brain regions of the male rat. J. Neurochem 60: 2254-2264, 1993.
80. Al-Wadei HA, Plummer HK III, Ullah MF, Unger B, Brody JR and Schuller HM: Social stress promotes and $\gamma$-aminobutyric acid inhibits tumor growth in mouse models of non-small cell lung cancer. Cancer Prev Res (Phila) 5: 189-196, 2012.

81. Al-Wadei HA, Al-Wadei MH, Masi T and Schuller HM: Chronic exposure to estrogen and the tobacco carcinogen NNK cooperatively modulates nicotinic receptors in small airway epithelial cells. Lung Cancer 69: 33-39, 2010.

82. Dionisio L, José De Rosa M, Bouzat C and Esandi Mdel C: An intrinsic GABAergic system in human lymphocytes. Neuropharmacol 60: 513-519, 2011.

83. Zhang X, Zhang R, Zheng Y, Shen J, Xiao D, Li J, Shi X, Huang L, Tang H, Liu J, et al: Expression of gamma-aminobutyric acid receptors on neoplastic growth and prediction of prognosis in non-small cell lung cancer. J Transl Med 11: 102, 2013.

84. Li YH, Liu Y, Li YD, Liu YH, Li F, Ju Q, Xie PL and Li GC: GABA stimulates human hepatocellular carcinoma growth through overexpressed GABAA receptor theta subunit. World J Gastroenterol 18: 2704-2711, 2012.

85. Liu Y, Guo F, Dai M, Wang D, Tong Y, Huang J, Hu J and Li G: Gammaaminobutyric acid A receptor alpha 3 subunit is overexpressed in lung cancer. Pathol Oncol Res 15: 351-358, 2009.

86. Delpire E and Mount DB: Human and murine phenotypes associated with defects in cation-chloride cotransport. Annu Rev Physiol 64: 803-843, 2002.

87. Galanopoulou AS: Sexually dimorphic expression of KCC2 and GABA function. Epilepsy Res 80: 99-113, 2008.

88. Shen MR, Lin AC, Hsu YM, Chang TJ, Tang MJ, Alper SL, Ellory JC and Chou CY: Insulin-like growth factor 1 stimulates $\mathrm{KCl}$ cotransport, which is necessary for invasion and proliferation of cervical cancer and ovarian cancer cells. J Biol Chem 279: 40017-40025, 2004.

89. Galanopoulou AS: Dissociated gender-specific effects of recurrent seizures on GABA signaling in CA1 pyramidal neurons: Role of GABA(A) receptors. J Neurosci 28: 1557-1567, 2008.

90. Hiraoka K, Miyazaki H, Niisato N, Iwasaki Y, Kawauchi A, Miki T and Marunaka Y: Chloride ion modulates cell proliferation of human androgen-independent prostatic cancer cell. Cell Physiol Biochem 25: 379-388, 2010.

91. Ohsawa R, Miyazaki H, Niisato N, Shiozaki A, Iwasaki Y, Otsuji E and Marunaka Y: Intracellular chloride regulates cell proliferation through the activation of stress-activated protein kinases in MKN28 human gastric cancer cells. J Cell Physiol 223: 764-770, 2010. 